\title{
Opal phytolith and isotopic studies of "Restinga" communities of Maricá, Brazil, as a modern reference for paleobiogeoclimatic reconstruction
}

\author{
Cátia Pereira dos Santos ${ }^{1}$, Heloisa Helena Gomes Coe ${ }^{1,2}$, Natalia Borrelli ${ }^{3}$, André Luiz \\ Carvalho da Silva², Leandro de Oliveira Furtado de Sousa ${ }^{4}$, Yame Bronze Medina Ramos ${ }^{1}$, \\ Carolina Pereira Silvestre ${ }^{1}$, Amanda Pacheco Seixas ${ }^{1}$
}

\author{
${ }^{1}$ Programa de Pós-Graduação em Dinâmica dos Oceanos e da Terra, Dept. de Geologia da UFF, Campus da Praia Vermelha \\ (Rua Passo da Pátria, 156, São Domingos, Niterói, RJ, CEP: 24.210-240, Brazil) \\ ${ }^{2}$ Departamento de Geografia da Faculdade de Formação de Professores da UERJ \\ (Rua Dr. Francisco Portela, 1470, Patronato, São Gonçalo, RJ, CEP: 24435-005, Brazil) \\ ${ }^{3}$ Instituto de Geología de Costas y del Cuaternario, UNMdP \\ (Funes 3350, Mar del Plata, Argentina) \\ ${ }^{4}$ Departamento de Ciências Vegetais da UFERSA, Universidade Federal Rural do Semi-Árido \\ (Av. Francisco Mota, 572, Presidente Costa e Silva, CEP: 59.625-900, Mossoró, RN, Brazil)
}

*Corresponding author: catia-ps@hotmail.com

Financial Support: FAPERJ

\section{Abstract}

The Maricá restinga, located in the eastern part of the Rio de Janeiro State (Brazil), corresponds to one of the few remaining preserved areas of the state's coastal plain. This paper reports on a study of the Maricá restinga plant communities and also presents an identification of the main plant species present in each community, with the objective of establishing reference collections, by the methods of the proxies opal phytoliths and stable carbon isotopes, for paleoenvironmental reconstructions of this coastal area during the Quaternary. Six plant communities, distributed perpendicularly to the coast line over sandy barriers, lagoonal plain, lagoon margin and weathered basement were identified: halophile-psamophile, scrub, herbaceous swamp, slack, shrubby vegetation and dry forest. In general, the plant species analyzed in each community presented low productivity of opal phytoliths, as only the Poaceae, Cyperaceae and Arecaceae families produce a great amount and diversity of morphotypes of opal phytoliths. The results of the analysis of stable carbon isotopes in sediments indicated a predominance of $\mathrm{C} 3$ or a mixture of $\mathrm{C} 3$ and $\mathrm{C} 4$ plants, presenting a close correlation with the results found in plants collected in each community. In conclusion, it was verified that the carbon isotope analysis associated with that of the opal phytoliths are good proxies for the reconstruction of vegetation in the study area.

Descriptors: Opal phytoliths, Carbon isotopes, Restinga, Plant communities, Maricá, Brazil.

\section{RESUMO}

A Restinga de Maricá, situada na porção leste do estado do Rio de Janeiro (Brasil), corresponde a uma das poucas áreas ainda preservadas na planície litorânea fluminense. Neste trabalho, apresentamos um estudo sobre as comunidades vegetais que compõem a restinga, bem como a identificação das principais espécies presentes em cada uma delas. $\mathrm{O}$ objetivo é estabelecer coleções de referência para reconstituições paleoambientais desse litoral durante o Quaternário. Para isso, utilizaram-se como métodos os indicadores fitólitos e isótopos estáveis de carbono. Foram identificadas seis comunidades vegetais distribuídas perpendicularmente à linha de costa sobre as barreiras arenosas, planície lagunar, margem lagunar e embasamento alterado: Halófila-psamófila, "Scrub", Brejo herbáceo, "Slack", Vegetação arbustiva e Floresta seca. As espécies de plantas analisadas em cada comunidade apresentaram em geral baixa produtividade de fitólitos. Somente as famílias Poaceae, Cyperaceae e Arecaceae produzem fitólitos em grandes quantidades e diversidade de morfotipos. Os resultados das análises de isótopos estáveis de carbono em sedimentos indicaram um predomínio de plantas $\mathrm{C} 3$ ou de mistura de plantas $\mathrm{C} 3$ e $\mathrm{C} 4$, apresentando uma boa correspondência com os resultados encontrados nas plantas coletadas sobre cada uma delas. Como conclusão, verificou-se que os isótopos de carbono associados às análises fitolíticas mostraram-se bons indicadores para a reconstituição da vegetação na área estudada.

Descritores: Silicofitólitos, Isótopos de carbono, Restinga, Comunidades vegetais, Maricá, Brasil. 


\section{INTRODUCTION}

This work aims to establish reference collections of modern plant opal phytoliths and carbon isotopes of sediments and plants in different plant communities of the Maricá restinga, in the state of Rio de Janeiro, for the paleobiogeoclimatic reconstruction of this coastline along the Quaternary.

The central portion of the coastal plain chosen for this study is represented by the Environmental Protection Area (EPA) of Maricá, also known as "Restinga de Maricá". This area has a typical geomorphology of sand barriers separated by lagoon systems parallel to the coast (SILVA, 2011). According to Conama (2002), restinga is "a sandy deposit parallel to the coastline, usually of elongated form, produced by sedimentation processes, where we can find different communities receiving marine influence, which may also be considered edaphic communities, because they depend more on the nature of the substrate than the climate. The vegetal cover in restingas occurs in mosaic and is found on beaches, sandy barriers, dunes and depressions, with (according to the successional stage) herbaceous, shrub and tree strata, the latter being more internalized". It can be seen that this definition of the concept of restinga involves both the geomorphological aspect and the vegetal composition. Several studies (SUGUIO; TESSLER, 1984; SILVA; OLIVEIRA, 1989; VILLWOCK, 1994; SUGUIO, 2003; among others) provide a definition for the word restinga associated only with vegetation cover formed over coastal sand deposits located along the Brazilian coast; this latter is the concept adopted in this study.

Opal phytoliths, one of the proxies used in this study, are microscopic particles of amorphous silica, formed as a result of the uptake of silicic acid $\left[\mathrm{Si}\left(\mathrm{OH}_{4}\right)\right]$ by the plants from the soil solution and which are incorporated into the soil from the decomposition of vegetal remains (PIPERNO, 1998). The choice of opal phytoliths is due, among other reasons, to the fact that this proxy is commonly found in different types of soil and/or sediments. The high degree of preservation of opal phytoliths, even under oxidative conditions, enables the specific and functional characterization of plants and paleoclimate inference, favors the understanding of the relationship between the evolution and degradation of soil and makes a better understanding of the biogeochemical cycle of silica (dissolution, preservation and transfer) possible (COE et al., 2012).
In addition, the data of stable carbon isotopes were used with the aim of complementing the phytolith results. The application of this proxy in environmental and paleoenvironmental studies is based on the fact that its isotopic composition varies in a predictable way, according to the cycle of the element in nature (ZAGATTO et al., 2010). In the case of plants, there is discrimination of carbon isotopes in the biological processes of the photosynthesis cycle and nitrogen 15N fixation (BERRIER; PROSSER, 1996). Therefore, the ratio between the stable carbon isotopes $(\delta 13 \mathrm{C})$ favors the identification of the type of plant from which the material analyzed originated, since its values express the path the primary producer used to assimilate $\mathrm{CO}_{2}$ and also the preferentially assimilated isotope (KILLOPS; KILLOPS, 2005). For its part, the isotopic analysis of the soil's organic matter (SOM) used in this study, permits the identification of the vegetation type that it originated from as being of type $\mathrm{C} 3$ (mainly trees) or C4 (mainly grasses) (PESSENDA et al., 2005).

Although several studies have contributed to knowledge of the formation and evolution of the Maricá coastal plain (LAMEGO, 1940; MUEHE, 1984; MUEHE; CORRÊA，1989; PERRIN，1984; IRELAND， 1987; TURCQ et al., 1999; PEREIRA et al., 2003, 2009; SILVA et al., 2014a, b), the use of opal phytoliths integrated into the study of stable carbon isotopes represents a pioneering contribution, aiming to characterize environmental changes which occurred in the Quaternary along this coast. Thus the establishment of modern phytolith and carbon isotope reference collections present in different plant communities of the restinga becomes essential for future paleobiogeoclimatic reconstructions of the coast of Maricá.

\section{STUDY AREA}

The Maricá restinga is located in the central portion of the Maricá coastal plain situated on the eastern coast of the state of Rio de Janeiro, about $20 \mathrm{~km}$ from the entrance to Guanabara Bay (Figure 1). The Environmental Protection Area of Maricá is approximately 8 kilometers long and covers a total area of about 800 ha. It was transformed into a conservation area by Decree № 7230 of January 23, 1984, although its Management Plan was established only in 2007. This part of the coastline of Maricá presents considerable biodiversity, with about 408 endemic species of flora and fauna that are threatened with extinction (LOUREIRO et al., 2010). 


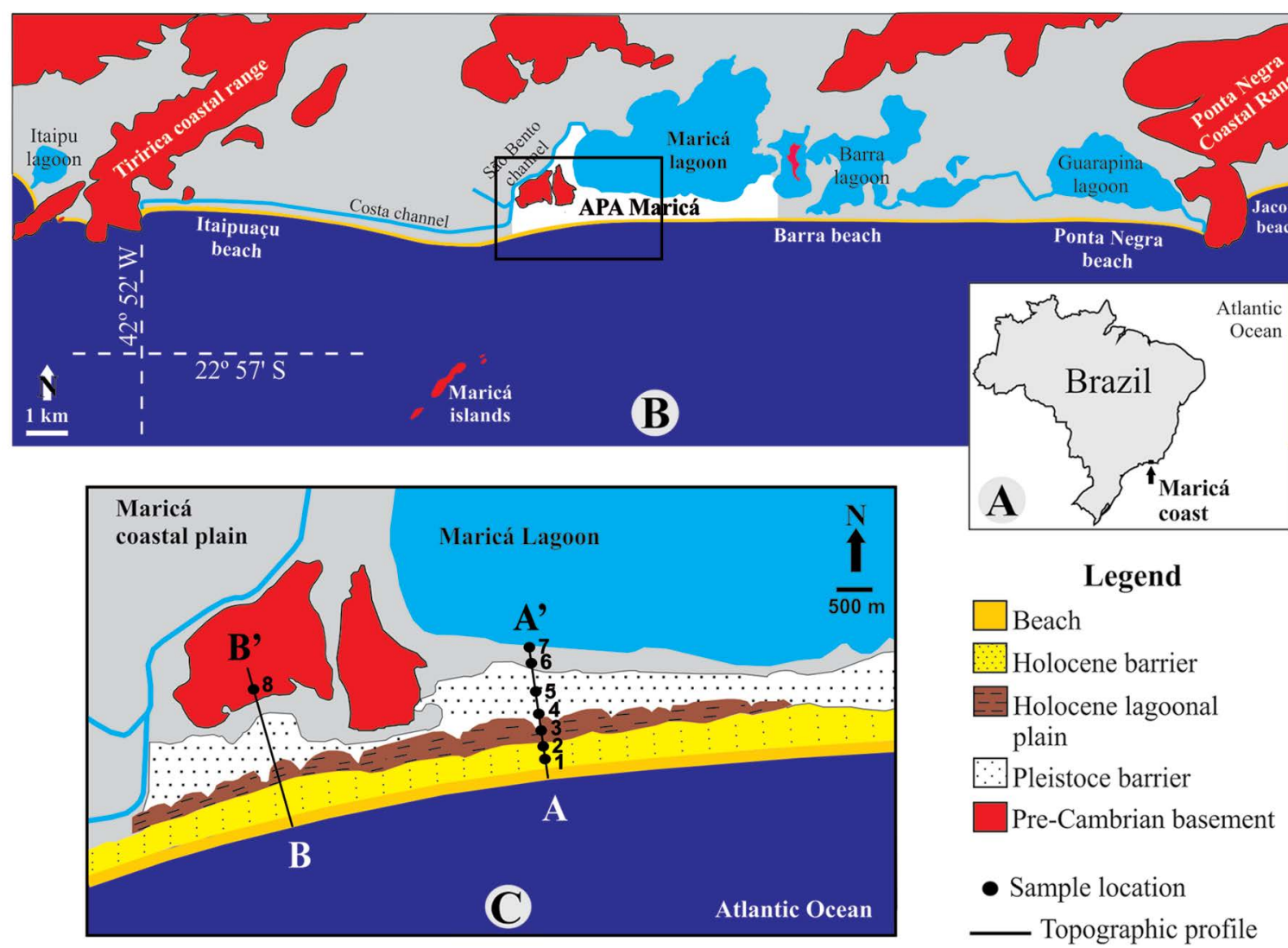

Figure 1. (A) Location of the study area in the state of Rio de Janeiro, southeastern Brazil; (B) Coastline of Maricá, with the EPA in the central portion of the coastal plain. (C) Major geomorphological characteristics and sampling sites.

The coastline of Maricá is characterized by direct exposure to high-energy waves, which can reach over 2 meters high in the surf zone during violent storm events (SILVA et al., 2008). The geomorphology of the EPA of Maricá is characterized by the existence of two sandy barriers separated by a narrow elongated lagoon plain and the large lagoon of Maricá rearward (Figures 1 and 2). The internal barrier (furthest from the ocean) is older, and was formed in the Pleistocene (IRELAND, 1987; TURCQ et al., 1999; SILVA et al., 2014a). This barrier is located about 300 meters from the first and has a height of 7-9 meters above mean sea level (SILVA et al., 2014b). The external barrier (closest to the ocean) was formed in response to a significant event occurring during the Holocene transgression (PERRIN, 1984; IRELAND, 1987; TURCQ et al., 1999; PEREIRA et al., 2003; SILVA et al., 2014a) and it has a height of about 7 meters in relation to mean sea level (SILVA et al., 2014b).

These sandy formations are covered by resting $a$ vegetation (Figure 2), with the presence of cactus, bromeliads and various species of grasses and low-growing shrubs. In response to the influence of factors such as insolation, topography, greater or lesser wind exposure, salt water intrusion, storm wave action and reach of the marine spray, and lack of nutrients and water in the soil, among others, the vegetation of the restinga presents great variability, being subdivided into different plant communities (CORTE, 2009). Among the existing classifications, we give preference to that of ARAÚJO and HENRIQUES (1984), which identified the following plant communities in restingas: Halophile, Psamophile-creeping plants, Slack of mobile dunes; Thicket; Scrub; herbaceous marsh; Seasonally flooded forest; Permanently flooded forest and Dry forest.

Although it is an EPA, this area is threatened as a consequence of haphazard occupation, which has been affecting the coastal ecosystems and artisanal fishing community of Maricá. A study of this coast by OLIVEIRA et al. (1955) had already raised a number of issues, such as problems related to flooding; frequent changes in the 


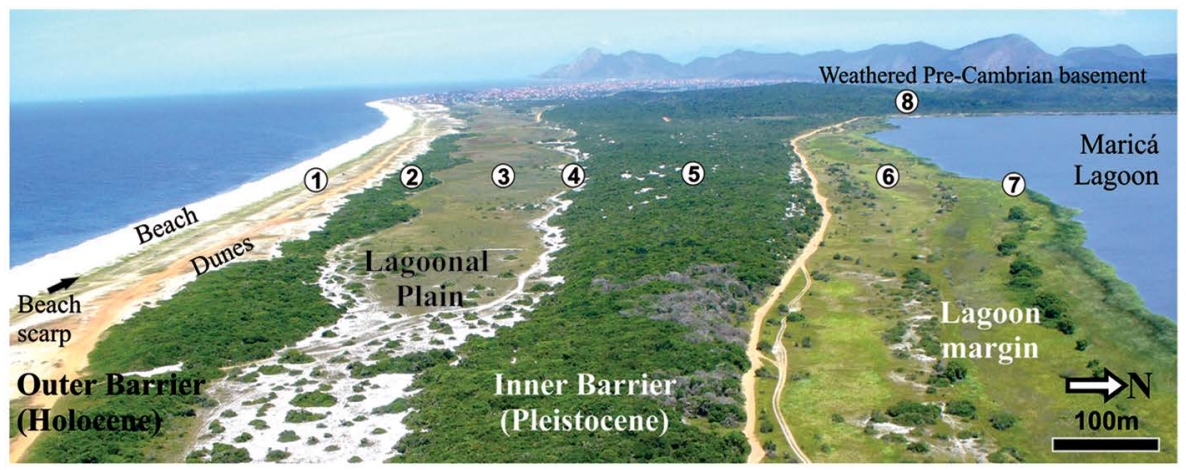

\section{LEGEND \\ 1. Halophile-psamophile}

2. Scrub

3. Herbaceous swamp

4. Slack

5. Scrub

6. Herbaceous swamp

7. Shrubby vegetation

8. Dry forest

Figure 2. Geomorphology and vegetal communities of the Maricá coastal plain (Photo: Guichard, 2009).

lagoon system, with the opening of channels and the release of raw sewage into the lagoons, causing a decrease in the fish population, as well as the problem of settlements resulting from increased land speculation at that time. The current situation in the region is one of abandonment, it being easy to find evidence of various aggressions to the environment, such as the illegal removal of sand, which is destroying the topography of the sand barriers; vehicles traversing the dunes and vegetated areas, destroying the local flora and fauna; illegal discharge of domestic waste; construction of houses and roads over restinga vegetation, causing deforestation; besides the constant action of criminals poaching wild animals (SILVA et al., 2014b).

\section{MATERIAL AND METHODS}

Eight sampling sites were chosen based on the different plant communities of the Maricá restinga, in view of geomorphological and hydrological factors (Figures $1 \mathrm{C}$ and 2). At each sampling site, samples of the most representative species of each plant community and samples of surface sediments were collected for isotopic and phytolith analyses (a total of 32 plants).

\section{Materials}

32 plants corresponding to different species present in the plant communities of the Maricá restinga were collected for phytolith and carbon isotope analysis (Table 1).

For the isotopic analysis 14 samples of surface sediments (below the litter) were also collected in each of the plant communities of the Maricá restinga. In the communities that present the highest diversity of plants and/or environmental conditions, more than one sample was collected (Table 2).
Methods

PHYTOLITH EXTRACTION AND DESCRIPTION OF PLANTS

The opal phytoliths' extraction from the leaves of the vegetal samples was performed at the Instituto de Geología de Costas y del Cuaternario, UNdMP, Argentina.

For each species, leaves from at least two plants were sampled and opal phytoliths were extracted following a calcination technique (LABOURIAU, 1983). The leaves were first placed in an ultrasound bath for 15-20 min and washed with distilled water to remove mineral contaminants. The samples were dried at $56^{\circ} \mathrm{C}$ for $24 \mathrm{~h}$, and charred at $200^{\circ} \mathrm{C}$ for $2 \mathrm{~h}$. Later, they were boiled in a $5 \mathrm{~N} \mathrm{HCl}$ solution for $10 \mathrm{~min}$, washed with distilled water and filtered with ashless filter paper, until no more chloride ions were detected. Finally, the samples were ignited at $760^{\circ} \mathrm{C}$ for $3 \mathrm{~h}$. The ashes were mounted with immersion oil and the phytolith morphotypes were observed and described with a Leitz Wetzlar D 35780 microscope at 400x magnification. Photographs were taken with a Kodak Easy Share CX7530 digital camera. Between 200 and 250 opal phytoliths were counted on each slide and the morphotypes were described according to the ICPN descriptors (MADELLA et al., 2005). Whenever possible, the relative frequency of each phytolith morphotype was also calculated.

\section{STABLE ISOTOPE ANALYSES}

Isotopic analyses of carbon were performed at the Laboratory of Isotope Ecology of CENA/USP. The samples were weighed in tin capsules using an analytical balance. The analyses of the elemental composition of organic matter concentrations were carried out in a Carlo Erba elemental analyzer model EA 1110 attached to a mass 
Table 1. Plants collected in each plant community of the Maricá

\begin{tabular}{|c|c|}
\hline Community & Species collected \\
\hline Halophile-psamophile & $\begin{array}{l}\text { Ipomoea pes-caprae (L.) R. Br. (Convolvulaceae); Alternanthera littoralis P. Beauv. (Amaranthaceae); } \\
\text { Remirea maritima Aubl. (Cyperaceae); Sporobolus virginicus (L.) Kunth. (Poaceae, Chloridoideae); Panicum } \\
\text { racemosum (P. Beauv.) Spreng. (Poaceae, Panicoideae); Stenotaphrum secundatum (Walt.) Kuntze (Poaceae, } \\
\text { Panicoideae). }\end{array}$ \\
\hline Scrub & $\begin{array}{l}\text { Clusia aff. fluminensis Planch. \& Triana (Clusiaceae); Neoregelia cruenta (Graham) L. B. Sm. } \\
\text { (Bromeliaceae); Anthurium sp. (Araceae); Allagoptera arenaria (Gomes) Kuntze (Arecaceae); sp1 } \\
\text { (Ericaceae); Smilax spinosa Mill. (Smilacaceae); Heteropteris chrysophylla (Lam.) Kunth (Malpighiaceae); } \\
\text { Clusia lanceolata Cambess. (Clusiaceae); Gaylussacia brasiliensis (Spreng.) Meisn. (Ericaceae); } \\
\text { Stigmaphyllon paralias A. Juss. (Malpighiaceae); Myrciaria sp. (Myrtaceae). }\end{array}$ \\
\hline Herbaceous swamp & $\begin{array}{l}\text { Sagittaria lancifolia L. (Alismataceae); Typha domingensis Pers. (Thyphaceae); sp1 (Rubiaceae); Fuirena } \\
\text { umbellata Rottb. (Cyperaceae); Eleocharis subariculata (Nees) Boeckler (Cyperaceae); Blechnum } \\
\text { serrulatum (Blechnaceae) }\end{array}$ \\
\hline Slack & Stachytarpheta sp. (Verbenaceae); sp2 (Rubiaceae); Erythroxylum ovalifolium Peyr. (Erythroxylaceae) \\
\hline Shrubby vegetation & $\begin{array}{l}\text { Hydrocotyle bonariensis Lam. (Apiaceae); Vernonia sp. (Asteraceae); Dalbergia ecastaphyllum (L.) Taub. } \\
\text { (Fabaceae). }\end{array}$ \\
\hline Dry forest & $\begin{array}{l}\text { Calathea sp. (Maranthaceae); Bromelia antiacantha Bertoloni (Bromeliaceae); Astrocaryum aculeatissimum } \\
\text { (Schott) Burret (Arecaceae), Clusia sp. (Clusiaceae). }\end{array}$ \\
\hline
\end{tabular}

Table 2. Surface sediments collected in the plant communities of the Maricá

\begin{tabular}{|c|c|c|}
\hline Vegetal community & Characteristics of the sampling site & $\begin{array}{l}\text { Geographical } \\
\text { coordinates }\end{array}$ \\
\hline \multirow{3}{*}{ Halophile-psamophile } & $\begin{array}{l}\text { Sample 1: On the beach, near the storm scarp. Sparse cover of grasses and other creeping } \\
\text { plants. }\end{array}$ & \multirow{3}{*}{$\begin{array}{l}22^{\circ} 57^{\prime} 55.5^{\prime \prime} \mathrm{S} \\
42^{\circ} 52^{\prime} 28.3^{\prime \prime} \mathrm{W}\end{array}$} \\
\hline & $\begin{array}{l}\text { Sample 2: On the beach, near the storm scarp. More dense vegetation cover, presence of } \\
\text { other types of grasses. }\end{array}$ & \\
\hline & $\begin{array}{l}\text { Sample 3: Holocene barrier in the upper flat portion rearward of the storm scarp. Presence } \\
\text { of other types of grasses and some cactus. }\end{array}$ & \\
\hline \multirow{4}{*}{ Scrub } & Sample 1: Lagoonal plain, close to the reverse of the Holocene barrier. & \multirow{4}{*}{$\begin{array}{l}22^{\circ} 57^{\prime} 45.6 ” \mathrm{~S} \\
42^{\circ} 51^{\prime} 43.8^{\prime \prime} \mathrm{W} \\
22^{\circ} 57^{\prime} 41.07^{\prime \prime} \mathrm{S} \\
42^{\circ} 52^{\prime} 27.01^{\prime \prime} \mathrm{W}\end{array}$} \\
\hline & Sample 2: Top of Pleistocene barrier. & \\
\hline & Sample 3: Pleistocene barrier in the reverse area. Diversified vegetation. & \\
\hline & Sample 4: Pleistocene barrier in the reverse field. Under clumps of Allagoptera arenaria & \\
\hline \multirow{5}{*}{ Herbaceous swamp } & Sample 1: Lagoonal plain, in the most flooded area of the marsh. & \multirow{5}{*}{$\begin{array}{l}22^{\circ} 57^{\prime} 49.6 ” \mathrm{~S} \\
42^{\circ} 52^{\prime} 27.6^{\prime \prime} \mathrm{W} \\
22^{\circ} 57^{\prime} 51.1^{\prime \prime} \mathrm{S} \\
42^{\circ} 52^{\prime} 47.4{ }^{\prime \prime} \mathrm{W} \\
22^{\circ} 57^{\prime} 34.5^{\prime \prime} \mathrm{S} \\
42^{\circ} 51^{\prime} 41.1^{\prime \prime} \mathrm{W}\end{array}$} \\
\hline & Sample 2: Lagoonal plain in the dry part of the marsh. Presence of other types of grasses. & \\
\hline & & \\
\hline & Sample 3: Plain between the reverse of the Pleistocene barrier and the Lagoon of Maricá. & \\
\hline & & \\
\hline Slack & Between the lagoonal plain and the front of the Pleistocene barrier. & $\begin{array}{l}22^{\circ} 57^{\prime} 47.8^{\prime \prime} \mathrm{S} \\
42^{\circ} 52^{\prime} 27.5^{\prime \prime} \mathrm{W}\end{array}$ \\
\hline Shrubby vegetation & Southern margin of the Lagoon of Maricá. & $\begin{array}{l}22^{\circ} 57^{\prime} 34.5 ” \mathrm{~S} \\
42^{\circ} 51^{\prime} 41.1 \% \mathrm{~W}\end{array}$ \\
\hline \multirow{2}{*}{ Dry forest } & Sample 1: Weathered Pre-Cambrian basement. Diverse woody vegetation. & \multirow{2}{*}{$\begin{array}{l}22^{\circ} 57^{\prime} 45.3^{\prime \prime} \mathrm{S} \\
42^{\circ} 53^{\prime} 16.9^{\prime \prime} \mathrm{W}\end{array}$} \\
\hline & Sample 2: Weathered Pre-Cambrian basement. Predominance of palm trees. & \\
\hline
\end{tabular}

spectrometer Finigan Delta Plus, allowing the simultaneous determination of organic carbon concentration and isotope signatures. Results are expressed as $\delta 13 \mathrm{C}$ relative to PDB (Pee Dee Belemnite) defined as $\delta 13 \mathrm{C}(\%$ - parts per thousand $)=([\mathrm{R}$ sample/R standard $]-1) \times 1000$. The samples were analyzed with a precision of $0.2 \%$. The limit of detection for $\mathrm{C}$ was $0.03 \%$.

\section{RESULTS AND DISCUSSION}

\section{Plant Communities of the Maricá restinga}

This study enabled us to identify the different plant communities that cover the sand barriers and the lagoonal plain in this preserved part of the coast of Maricá. 
Thus, based on ARAÚJO and HENRIQUES (1984), the following plant communities were found: Halophilepsamophile, Scrub, Herbaceous marsh, Slack, Shrubby vegetation on the margin of Maricá lagoon and Dry forest (Figure 3). These communities present a pattern of distribution which is perpendicular to the coastline and is strongly influenced by the topographic variability of the various geomorphological environments existing in the area (beach, barriers, dunes, lagoonal depression, etc.), by the reach of the marine spray and saline wedge, the proximity to the water table, which reaches the surface in the area of the lagoonal plain, and various edaphic conditions.

a) Halophile-psamophile (Figure 3): vegetation adapted to saline and sandy conditions under tidal influence, predominating herbaceous creeping species such as Ipomoea pes-caprae (Convolvulaceae), Alternanthera littoralis (Amaranthaceae), Remirea maritima (Cyperaceae), in addition to grasses such as Panicum racemosum (Poaceae). In areas beyond the reach of the waves, Rhipsalis sp. (Cactaceae), which promotes densification of the surrounding vegetation, and Stenotaphrum secundatum (Poaceae) can be found (Figure 4A, 4B and 5.1).

b) Scrub (Figure 3): open vegetation with thickets, where shrub species Clusia fluminensis (Clusiaceae), Heteropteris chrysophylla (Malpighiaceae), Erythroxylum ovalifolium (Erythroxylaceae) and some Ericaceae predominate. Among the herbaceous species, Neoregelia cruenta (Bromeliaceae) is dominant and also pioneers the process of thicket forming. Species such as Selenicereus setaceus (Cactaceae),
Anthurium sp. (Araceae) and many epiphytes like Tillansia stricta (Bromeliaceae) are also found. In the shrub layer, species like Tocoyena bullata (Rubiaceae), Ouratea cuspidata (Ochnaceae), Cereus fernambucensis (Cactaceae) and Myrciaria sp. (Myrtaceae) are common. Some thickets present the dominance of Hetropteris chysophylla (Malpighiaceae) and others were formed from Allagoptera arenaria (Arecaceae) (Figure 4C, D, 5B, 5.2 and 5.3).

c) Herbaceous swamp: two plant communities were located, one between the two sandy barriers (Figure 3) and the other near the Maricá lagoon (Figure 3), with a predominance of the Poaceae and Cyperaceae families, Sagittaria lancifolia (Alismataceae), Typha domingensis (Typhaceae), Marcetia taxifolia (Melastomataceae), Ludwigia octovalvis (Onagraceae) and Blechnum serrulatum (Blechnaceae) (Figure 4E-F, 4K-L, 6.1 and 6.2).

d) Slack (Figure 3): narrow stretch with creeping vegetation composed of Cuphea flava (Lythraceae), Stachytarpheta sp. (Verbenaceae), and grasses (Figure 4G-H and 6.3).

e) Shrubby vegetation on the margin of Maricá lagoon (Figure 3): these species form a continuous line around the lagoon of about 4 meters in height. It is a more disturbed area so there is a greater occurrence of invasive species such as Sansevieria trifasciata (Asparagaceae) and Euphorbia tirucalli (Euphorbiaceae). Among the dominant species are found Dalbergia ecastaphyllum (Fabaceae), Cordia verbenacea (Boraginaceae),
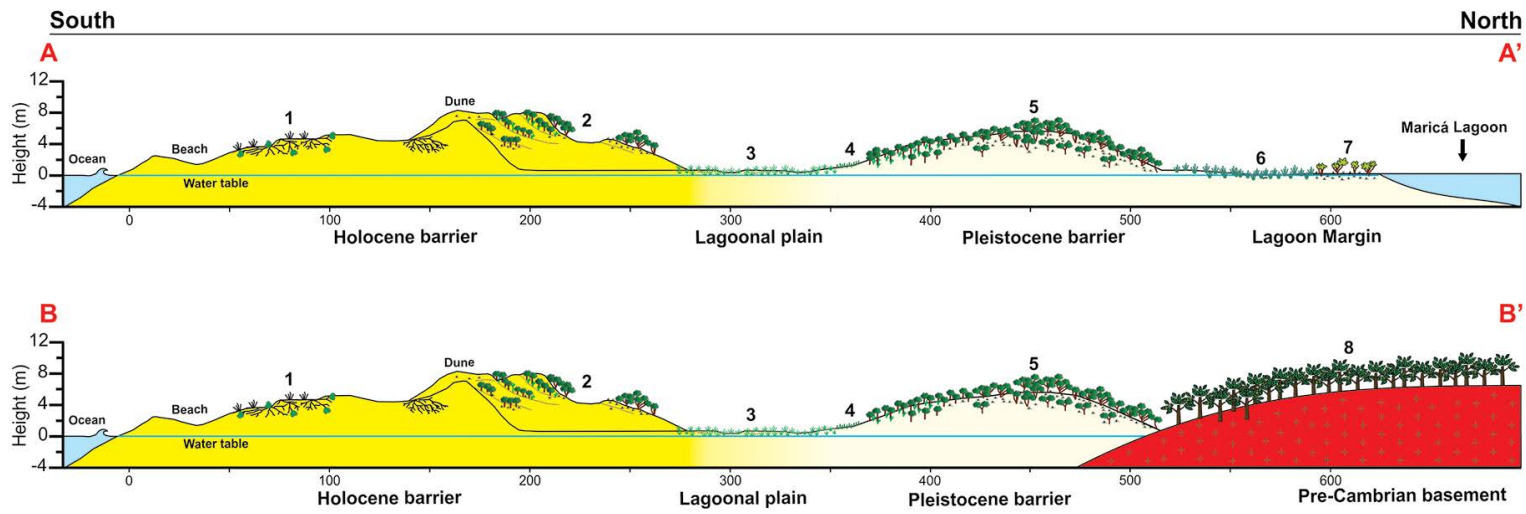

Figure 3. Plant communities of the EPA of Maricá (modified from Araújo; Henriques, 1984). Plant Communities: 1) Halophile-psamophile, 2) Holocene barrier scrub, 3) Herbaceous swamp, 4) Slack, 5) Pleistocene barrier scrub, 6) Herbaceous swamp near the Maricá lagoon, 7) Shrubby vegetation on the margin of Maricá lagoon, 8) Dry Forest. Geomorphology and depositional systems based on Silva et al. (2014a). 

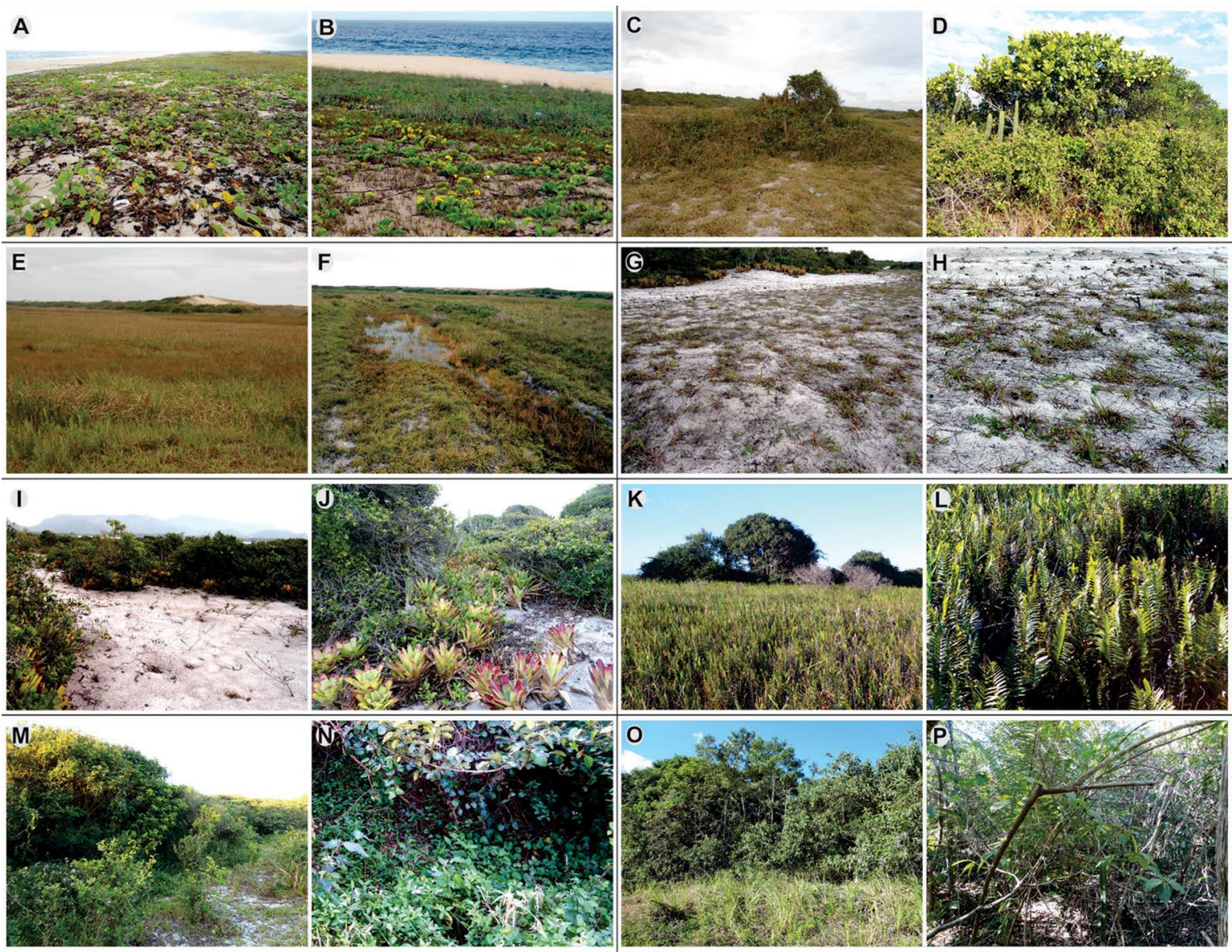

Figure 4. Overview of the areas occupied by the plant communities: A-B) halophile-psamophile; C-D) Holocene barrier scrub; E-F) herbaceous swamp in the lagoon plain; G-H) slack; I-J) Pleistocene barrier scrub; K-L) herbaceous swamp next to the Maricá lagoon; M-N) shrubby vegetation on the margin of Maricá lagoon; O-P) dry forest community on the weathered Pre-Cambrian basement. For each community the first photo is an overview and the second shows the detail of the predominant plants.

Schinus terebinthifolius (Anacardiaceae) and Hydrocotyle bonariensis (Apiaceae) (Figure 4M-N and 6.4).

f) Dry Forest (Figure 3): community without a dominant tree species, while in the herbaceous layer large populations of Calathea sp. (Marantaceae), Bromelia antiacantha (Bromeliaceae) and Astrocaryum aculeatissimum (Arecaceae) dominate (Figure 4O-P and 6.5).

\section{PHYTOLITHS FROM PLANTS}

\section{A) HaLOPHILE-PSAMophiLE COMMUNITY}

Among the species analyzed in this community, only the specimens belonging to Poaceae and Cyperaceae families produced opal phytoliths. This is in agreement with the bibliography that defines the two plant families as the major producers of opal phytoliths (PIPERNO, 1988).
Ipomoea pes-caprae (Convolvulaceae) (Figure 5.1A): only the presence of cylindrical sulcate tracheids in trace amounts was observed. According to WALLIS (2003), PARR (2005) and PIPERNO (2006), the Convolvulaceae Family is a non-producer of opal phytoliths. Some species were analyzed (Ipomea aquatica, I. muelleri, I. batata, I. congesta, Polymeria lanata) in which no opal phytoliths were observed (WALLIS, 2003; PARR, 2005).

Sporobolus virginicus (Poaceae, Chloridoideae) (Figure 5.1B): the major morphotype of phytolith is horned tower $(93.28 \%)$. Besides this, silica skeletons were also observed, being composed of horned tower and elongate types (3.9\%); elongate $(2.26 \%)$; horned tower, hair cells and elongate $(0.28 \%)$; and isolated hair cells $(0.28 \%)$ (Figure 7.1A). MERCADER et al. (2010) have reported the presence of tower and saddle phytoliths as the major morphotypes along with bilobate, conical, cross and trapeziform crenate phytoliths in the Chloridoideae subfamily. 
HALOPHILE-PSAMOPHILE
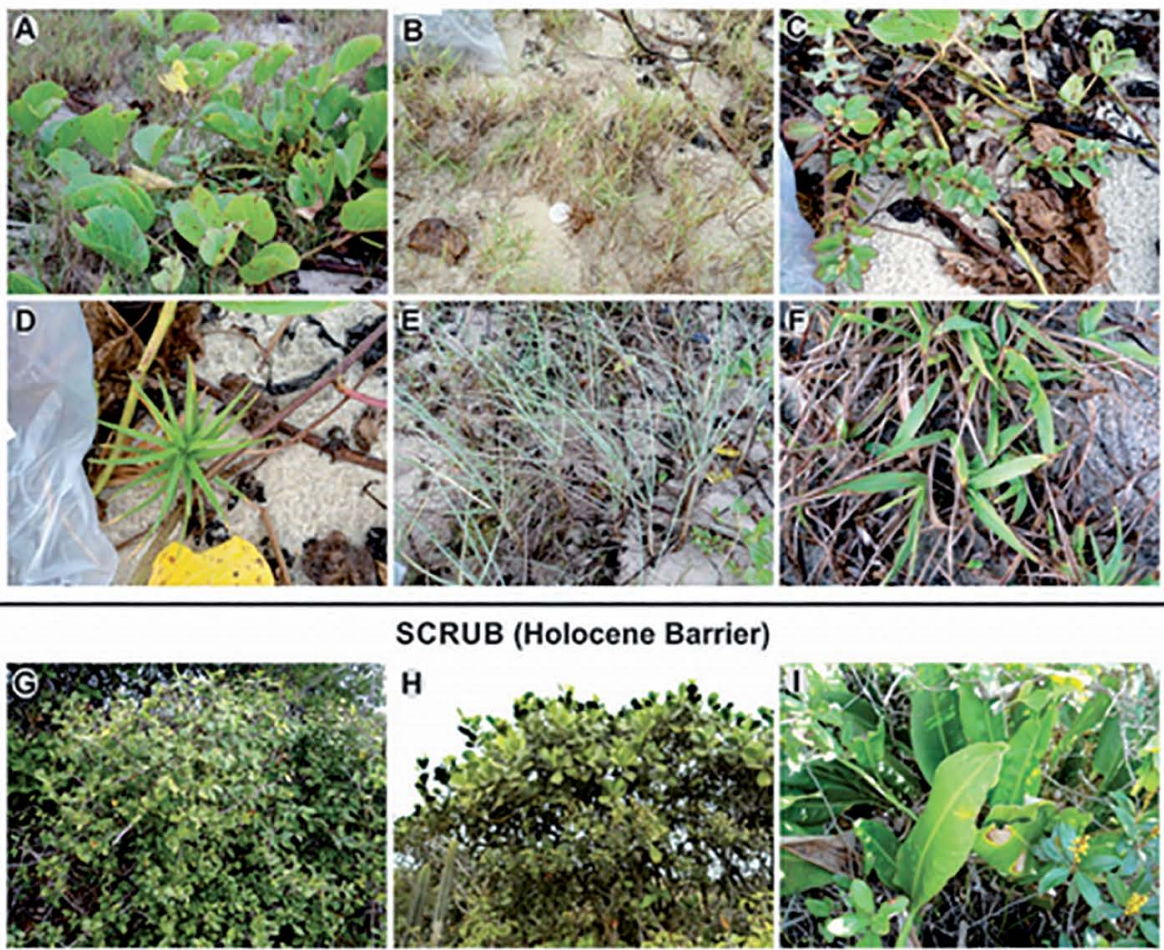

SCRUB (Holocene Barrier)

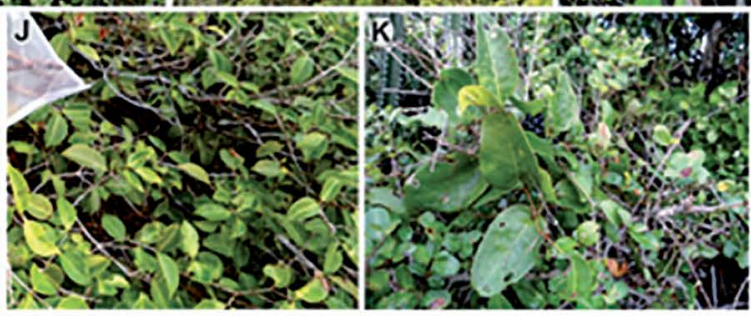

SCRUB (Pleistocene Barrier)
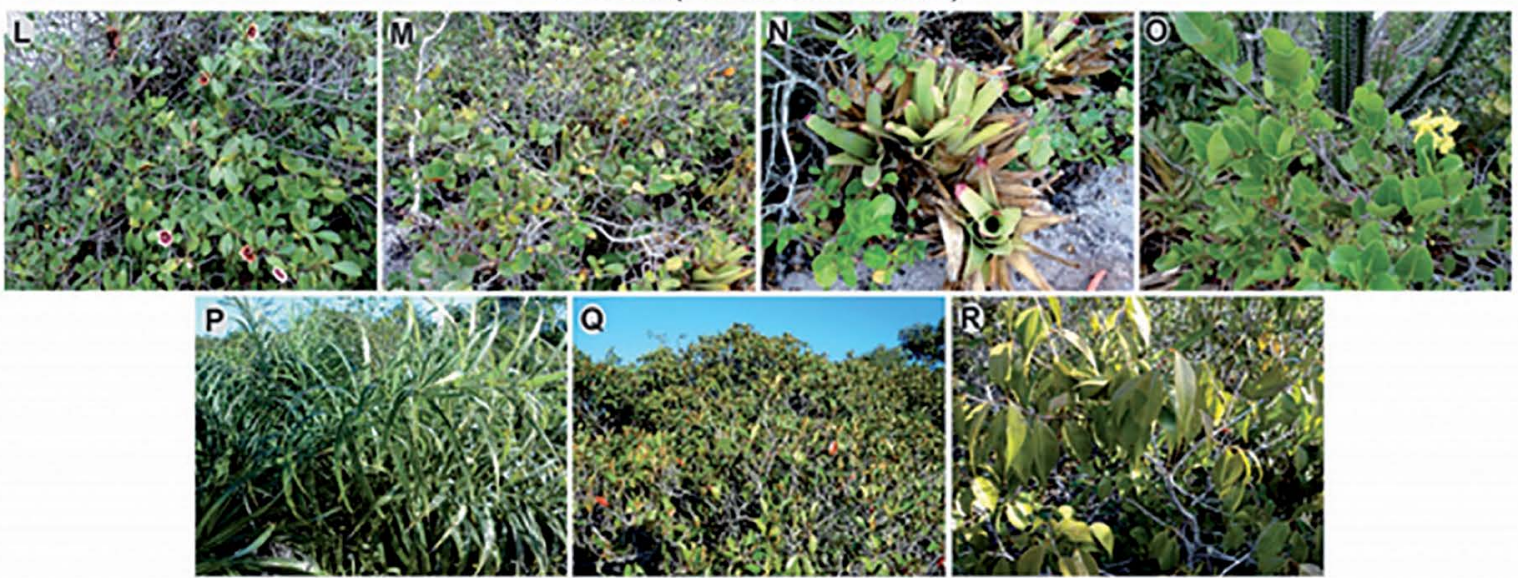

Figure 5. Detail of the collected plant species in: 1) the halophile-psamophile community: A) Ipomoea pes-caprae, B) Sporobolus virginicus, C) Alternanthera littoralis, D) Remirea maritima, E) Panicum racemosum, F) Stenotaphrum secundatum; 2) the Holocene barrier scrub community: G) Gaylussacia brasiliensis, H) Clusia aff. fluminensis, I) Anthurium sp, J) Heteropteris chrysophylla, K) Smilax spinosa, 3) the Pleistocene barrier scrub community: L) Clusia lanceolata, M) Heteropteris chrysophylla, N) Neoregelia cruenta, O) Stigmaphyllon paralias, P) Allagoptera arenaria, Q) Ericaceae sp1, R) Myrciaria sp. 
HERBACEOUS SWAMP (Lagoonal plain)

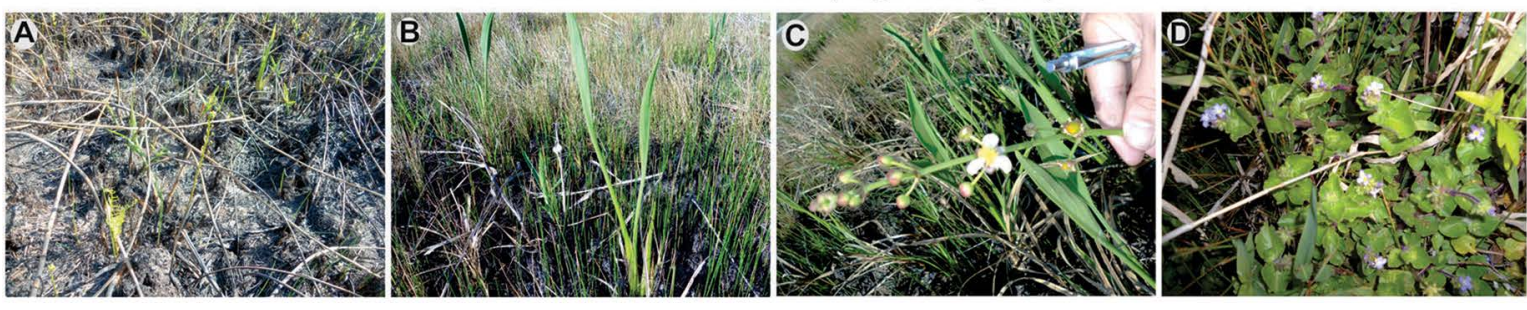

\section{HERBACEOUS SWAMP (near the Marica Lagoon)}

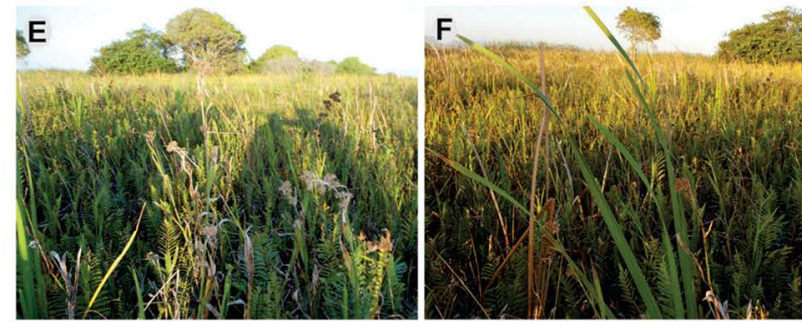

\section{SLACK}
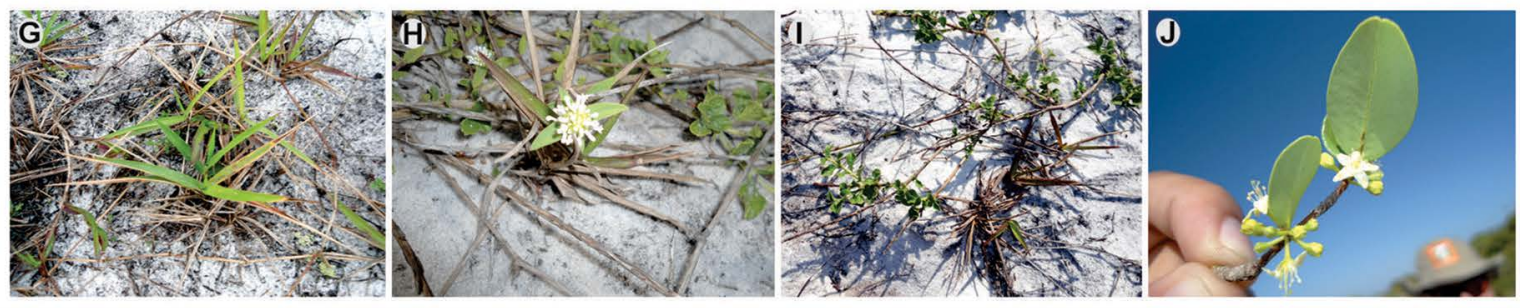

\section{SHRUBBY VEGETATION}
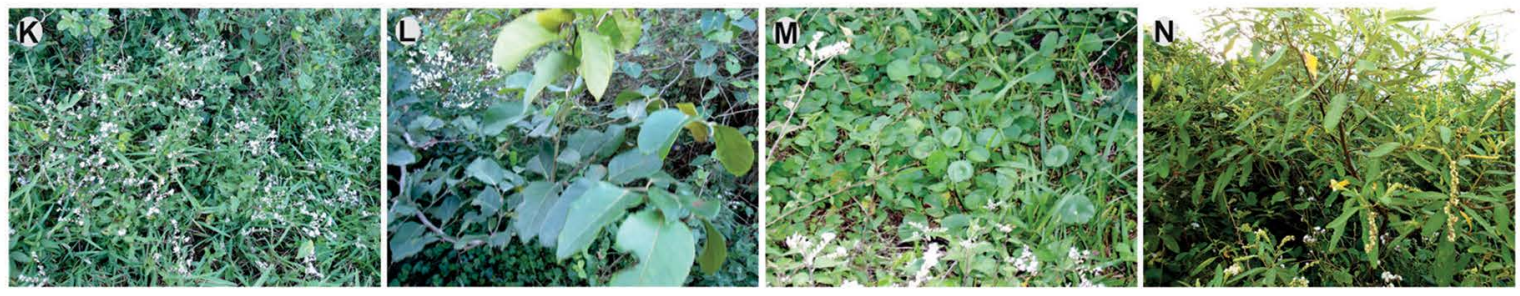

DRY FOREST
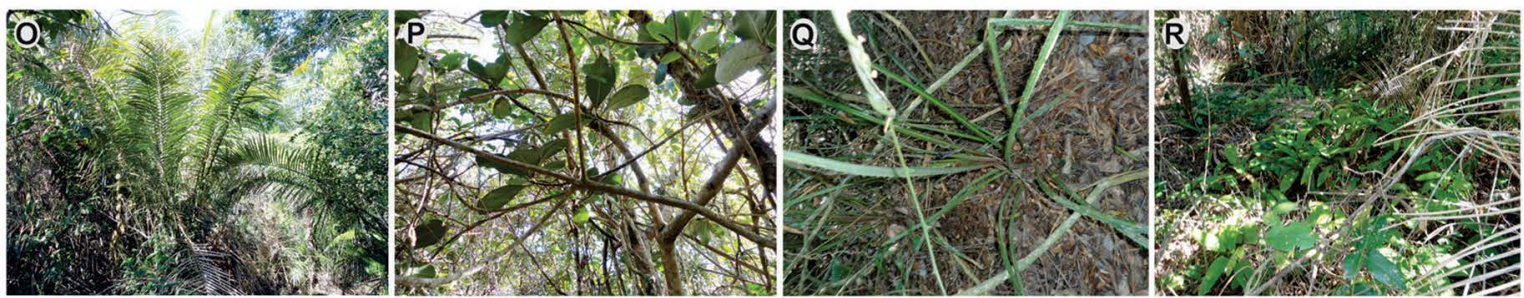

Figure 6. Detail of the collected plant species in: 1) the herbaceous swamp community on the lagoonal plain: A) Blechnum serrulatum, B) Eleocharis subarticulata, C) Sagittaria lancifolia, D) Rubiaceae sp1;2) the herbaceous swamp community near the Maricá lagoon: E-F) Fuirena umbellata; 3) the slack community: G) Stenotaphrum secundatum, H) Rubiaceae sp2, I) Stachytarpheta sp, J) Erythroxylum ovalifolium; 4) the shrubby vegetation on the margin of Maricá lagoon: K) Asteraceae sp1, L) Fabaceae Dalbergia ecastaphyllum, M) Hydrocotyle bonariensis, N) Schinus terebinthyfolius; 5) the dry forest community: O) Astrocaryum aculeatissimum, P) Clusia sp., Q) Bromelia antiacantha, R) Calathea sp. 


\section{HALOPHILE-PSAMOPHILE COMMUNITY}

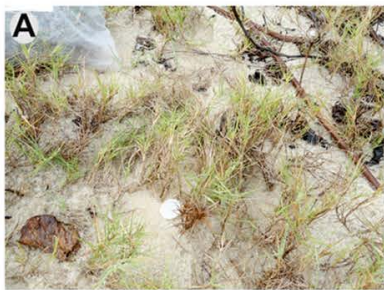

Sporobolus virginicus

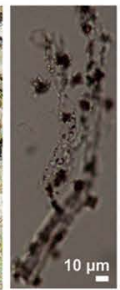

Horned Tower

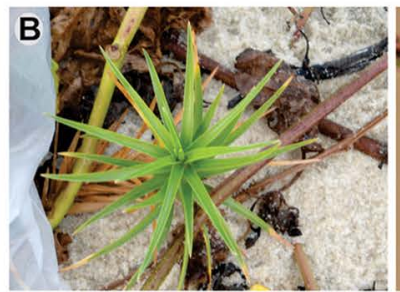

Remirea maritima

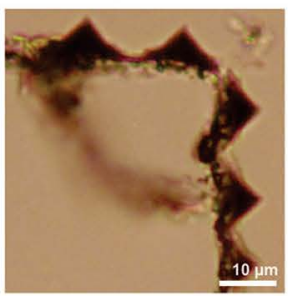

Cone Shape

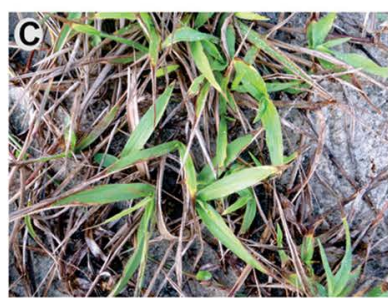

Stenotaphrum secundatum

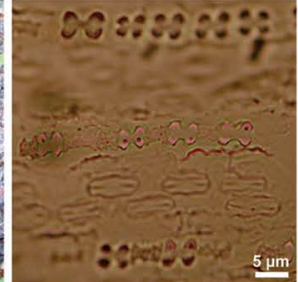

Cross

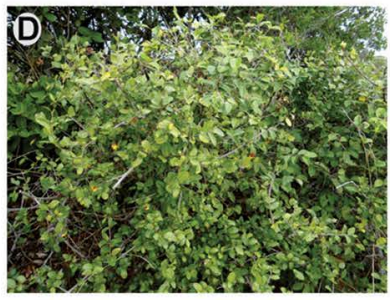

Gaylussacia cf. brasiliensis

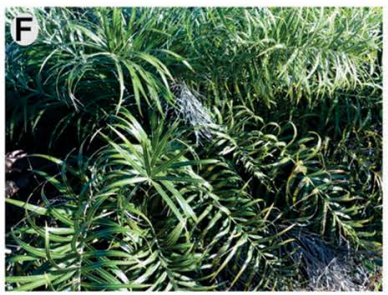

Allagoptera arenaria

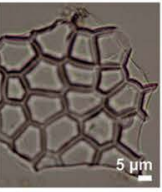

Polyhedral

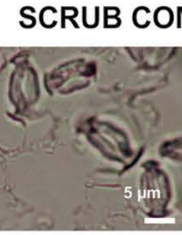

Stomate

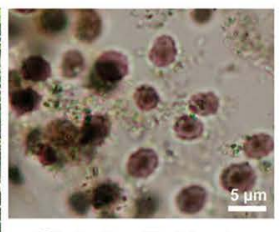

Globular Echinate

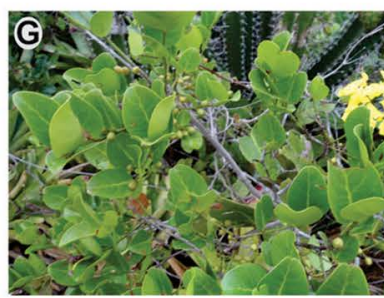

Stigmaphyllon paralias

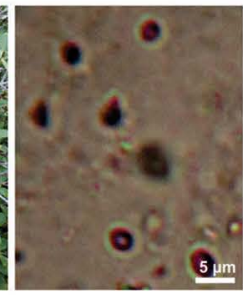

Globular Psilate

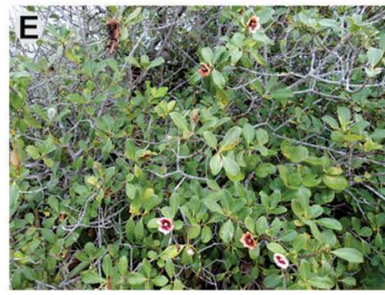

Clusia lanceolata

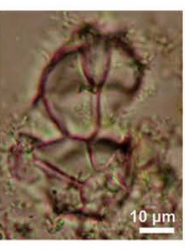

Stomate

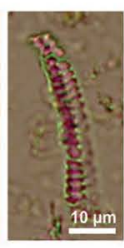

Cylindric Sulcate Tracheid

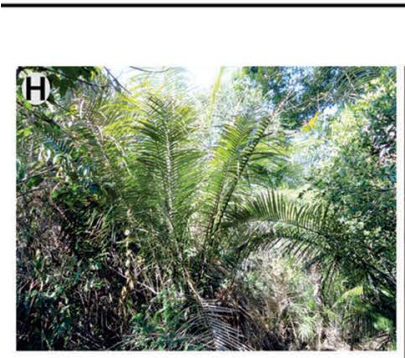

Astrocaryum aculeatissimum

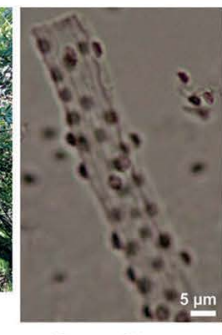

Cone Shape

DRY FOREST COMMUNITY

Figure 7. Dominant opal phytolith morphotypes in the opal phytolith producer species of the: 1) halophile-psamophile community: A) Sporobolus virginicus, B) Remirea maritima, C) Stenotaphrum secundatum; 2) scrub community: D) Gaylussacia brasiliensis, E) Clusia lanceolata, F) Allagoptera arenaria, G) Stigmaphyllon paralias; 3) dry forest: H) Astrocaryum aculeatissimum, I) Clusia sp. 
Generally, the production of opal phytoliths in different species of genus Sporobolus has been cited, but more specifically, the production of horned tower, saddle, cross and bilobate morphotypes has been reported in S. cryptandrus, $S$. airoides and $S$. consimilis (PIPERNO, 1988; MORRIS, 2009; MERCADER et al., 2010).

Alternanthera littoralis (Amaranthaceae) (Figure 5.1C): no opal phytoliths were observed, in agreement with previous reports. The Amaranthaceae family has been defined as a non-producer of opal phytoliths (WALLIS, 2003; PIPERNO, 2006). A few species of this family were analyzed (Acyranthes aspera, Aerva javanica, Althernanthera philoxeroides, Amaranthus retroflexus, Gomphrena canescens, Ptilotus corymbosus, P. exaltus, P. fusiformis, P. lanatus) without observing any phytolith production or only cylindrical sulcate tracheids in trace amounts (MULLHOLAND; RAPP, 1992; WALLIS, 2003; BORRELLI et al., 2011).

Remirea maritima (Cyperaceae) (Figure 5.1D): the main morphotype is the cone, typically of the Cyperaceae family, with a square base of about $12.5 \mu \mathrm{m}$ width and 2.5-5 tall. Generally, we observed a large proportion of articulated (76.65\%) and isolated cones (9.8\%). In addition, silica skeletons were also observed, being composed of cone and elongate phytoliths $(6.1 \%)$, psilate elongate phytoliths $(2.8 \%)$, stellate cells $(0.9 \%)$, stomatal complexes and paralellepipedal psilate cells $(0.9 \%)$, subepidermal cells $(0.5 \%)$; and isolated stomatal complexes $(2.35 \%)$ (Figure 7.1B). This description is in agreement with previous reports on the Cyperaceae family, in which it is classified as a silica accumulator (PIPERNO, 1988), and the cones are described as the phytolith diagnostic morphotype at family level (PIPERNO, 1988; FERNÁNDEZ HONAINE et al., 2009).

Stenotaphrum secundatum (Poaceae, Panicoideae) (Figure 5.1F): the dominant phytolith morphotypes are panicoid bilobate $(29.63 \%)$ and cross $(18.5 \%)$ in concordance with other species of the Panicoideae subfamily (FERNÁNDEZ HONAINE et al., 2006). Moreover, silica skeletons were also found, being composed of panicoid bilobate $(15.74 \%)$, panicoid bilobate and stomatal complexes $(6.5 \%)$, crenate elongate $(2.77 \%)$, panicoid bilobate and cross $(2.3 \%)$, polylobate $(1.39 \%)$, psilate elongate $(0.93 \%)$, stomatal complexes $(0.93 \%)$, long cells with silicified cell wall and panicoid bilobate $(1.39 \%)$ and cross phytoliths $(0.93 \%)$. Among the isolated morphotypes psilate elongate $(4.1 \%)$, polylobate $(4.63 \%)$ and jug-shaped cells ( $25 \mu \mathrm{m}$ tall, $20 \mu \mathrm{m}$ base width and $10 \mu \mathrm{m}$ top width) $(9.26 \%)$ were observed (Figure $7.1 \mathrm{C})$.

\section{B) SCRUB COMMUNITY}

Among the 8 plant species analyzed in this community, only four species produce opal phytoliths but in very low amounts, so the different morphotypes could not be quantified.

Gaylussacia brasiliensis (Ericaceae) (Figure 5.2G): a low degree of silicification was observed, only the presence of silica skeletons composed of the silicification of the cell wall of polyhedral epidermal cells and stomatal complexes; and isolated stomatal complexes being noted (Figure 7.2D). There are previous reports on the production of opal phytoliths in different species of the Ericaceae family. In leaves, wood and branches of Arctostaphylos uva-ursi, Calluna vulgaris, Loiseleuria procumbens, Rhododendron ferrugineum, Vaccinium myrtillus, $V$. vitis-idaea, the silicification of the stomatal complexes, trichomes and elongate crenate cells was observed (CARNELLI et al., 2004). BUJAN (2013) observed the production of polyhedral phytoliths in leaves in Calluna vulgaris, in agreement with our study. In Dracophyllum longifolium and D. scoparium the presence of rondel and elongate phytoliths was reported.

Clusia aff. fluminensis (Clusiaceae) (Figure 5.2H): no opal phytoliths were observed.

Clusia lanceolata (Clusiaceae) (Figure 5.3L): the presence of globular psilate phytoliths of about 2.5-5 $\mu \mathrm{m}$ diameter was observed in trace amounts (Figure 7.2E). It was reported that the phytolith production in the Clusiaceae family varies considerably among subfamilies and tribes; and that the diagnostic morphotypes are very scarce (PIPERNO, 2006). KEALHOFFER and PIPERNO (1998) had analyzed some genera and species of the family with differing results. Cratoxylon sp., Hypericum sp. (both genera currently in Hipericaceae) and Clusia rosea produce no opal phytoliths. Only cylindrical sulcate tracheids were observed in Garcinia sp. Calophyllum sp. produces tracheids and rugulose spheres of about 20-24 $\mu \mathrm{m}$ diameter and Mammea siamensis tiny spheres of $4 \mu \mathrm{m}$ diameter. In accordance with our results, MERCADER et al. (2009) reported the production of globular psilate phytoliths in leaves, but not in the stems of the Clusiaceae family.

Heteropteris chrysophylla (Malpighiaceae) (Figure 5.2J): no opal phytoliths were observed.

Stigmaphyllon paralias (Malpighiaceae) (Figure 5.30): a very low production of opal phytoliths was registered, with only some cylindrical sulcate tracheids and silica skeletons composed of stomatal complexes and epidermal cells. The production of opal phytoliths in the Malpighiaceae 
family is very rare or not common (PIPERNO, 2006). There is a report of the presence of silica in the fruit of Bunchosia armeniaca, but not of diagnostic morphotypes (CHANDLER-EZELL et al., 2006) (Figure 7.2G).

Smilax spinosa (Smilacaceae) (Figure 5.2K). No opal phytoliths were observed, in agreement with previous reports that describe the Smilaceae family as very rare or as a non-producer of opal phytoliths (PIPERNO, 2006).

Neoregelia cruenta (Bromeliaceae) (Figure 5.3N): although it is reported that the production of globular echinate opal phytoliths in the Bromeliaceae family is possible (PIPERNO, 2006), no opal phytoliths were observed in this species.

Allagoptera arenaria (Arecaceae) (Figure 5c): the production of globular echinate phytoliths of about 5-7.5 $\mu \mathrm{m}$ diameter was observed (Figure 7.2F). The Arecaceae family is one of the greatest phytolith producers along with Poaceae and Cyperaceae. The diagnostic morphotype is globular echinate, but it is also possible to observe conical and hat-shaped phytoliths (KEALHOFFER; PIPERNO, 1998; WALLIS, 2003; PIPERNO, 2006).

\section{C) SLACK COMMUNITY}

In this plant community, only Stenotaphrum secundatum (Poaceae, Panicoideae) was collected (Figure 6.3G). This species is also common in the halophile-psamophile community, so its phytolith production is described and illustrated in that item (Figure 7.1C).

\section{D) SHrub VegEtation on the Margins of MARICÁ LAGOON COMMUNITY}

In this plant community, only Hydrocotyle bonariensis (Apiaceae) was analyzed (Figure $6.4 \mathrm{M}$ ), and no opal phytoliths were observed. The Apiales order has been described as a non-producer of diagnostic morphotypes (KEALHOFFER; PIPERNO, 1998). Some species were studied and the results are variable. MERCADER et al. (2009) observed the presence of globular granulate opal phytoliths in species of the family; and bilobate, polylobate, rondel and elongate phytoliths were observed in Anisotome antipoda, A. latifolia and Stilbocarpa polaris (THORN, 2004). Furthermore, WALLIS (2003) found no opal phytoliths in Trachymene didiscoides and T. oleracea.

\section{E) DRY FOREST}

Astrocaryum aculeatissimum (Arecaceae) (Figure 6.50): this species produces conical phytoliths as its major morphotype (78\%). This morphology has a circular to eliptic base of $4-5 \mu \mathrm{m}$ diameter and $1.5 \mu \mathrm{m}$ high. Besides this, we also observed elongated phytoliths, probably silicified fibers, associated with conical phytoliths $(15 \%)$ and square epidermal cells with their cell walls silicified (5\%) (Figure 7.3H). These results are in agreement with the previous studies of the Arecaceae family, in which the production of globular echinate and conical phytoliths as common morphotypes has been described (KEALHOFFER; PIPERNO, 1998; PIPERNO, 2006).

Clusia sp. (Clusiaceae) (Figure 6.5P): the presence of globular psilate phytoliths of about 2.5-4 $\mu \mathrm{m}$ diameter was observed in trace amounts (Figure 7.3I). As previously cited, the phytolith production in the Clusiaceae family varies considerably between subfamilies and tribes, and the diagnostic morphotypes are very scarce (PIPERNO, 2006). Among all the reports analyzed, the results obtained by MERCADER (2009) are in agreement with our results, as the production of globular psilate phytoliths has been reported in leaves of the species of the Clusiaceae Family.

\section{Stable CARbon Isotopes}

For the stable carbon isotopes proxy, plants and surface sediments from each of the plant communities in the Maricá restinga were analyzed. The results are shown in Table 3 and described below.

In Brazil, especially in Rio de Janeiro State, there are few studies of vegetation reconstruction using the carbon isotopes proxy, as observed by BUSO et al. (2013). For resting a plants, these studies are even more rare. Because these plants can also be present in other ecosystems, we have tried to relate, wherever possible, the results obtained in this study to those of other authors such as KRULL et al. (2005), BOUTTON et al. (1998) and VIDOTTO et al. (2007).

\section{A) HALOPHILE-PSAMOPHILE COMMUNITY}

$\delta 13 \mathrm{C}$ values obtained for the sediment samples 1 and 2 were -22.84 and -22.37 , respectively, indicating the predominance of $\mathrm{C} 3$ plants, in this case not woody, such as Convolvulaceae Ipomoea pes-caprae (-25.93) and Amaranthaceae Alternanthera littoralis (-26.42), we also noticed the presence of $\mathrm{C} 4$ grasses such as Poaceae Sporobolus virginicus (-14.75) and Panicum racemosum (-12.8), as well as Cyperaceae Remirea maritima (-12.18). Similar $\delta 13 \mathrm{C}$ values were found by VIDOTTO et al. (2007) in southern Amazonas for other species of C4 grasses of the Poaceae family: Andropogon bicornis 
Table 3. Results of stable carbon isotopes of sediments and plants of the Maricá restinga (Sample number indicated in parenthesis).

\begin{tabular}{|c|c|c|c|c|}
\hline Vegetal community & $\delta 13 \mathrm{C}$ of the sediment & Family & Species & $\delta 13 C$ \\
\hline \multirow{6}{*}{ Halophile-psamophile } & & Convolvulaceae & Ipomoea pes-caprae (L.) R. Br. & -25.93 \\
\hline & $-22.60(1)$ & Amaranthaceae & Alternanthera littoralis $\mathrm{P}$. Beauv. & -26.42 \\
\hline & \multirow{2}{*}{$-22.37(2)$} & Cyperaceae & Remirea maritima Aubl. & -12.18 \\
\hline & & Poaceae & Sporobolus virginicus (L.) Kunth & -14.75 \\
\hline & \multirow[t]{2}{*}{$-18.43(3)$} & Poaceae Panicoideae & Panicum racemosum (P. Beauv.) Spreng. & -12.8 \\
\hline & & Poaceae Panicoideae & Stenotaphrum secundatum (Walt.) Kuntze & -11.51 \\
\hline \multirow{11}{*}{ Scrub } & \multirow[b]{4}{*}{$-26.35(1)$} & Clusiaceae & Clusia aff. fluminensis Planch. \& Triana & -26.59 \\
\hline & & Bromeliaceae & Neoregelia cruenta (Graham) L. B. Sm. & -12.68 \\
\hline & & Araceae & Anthurium sp. & -28.34 \\
\hline & & Arecaceae & Allagoptera arenaria (Gomes) O. Kuntze & -26.68 \\
\hline & \multirow[t]{2}{*}{$-22.25(2)$} & Ericaceae & $\mathrm{sp} 1$ & -27.99 \\
\hline & & Smilacaceae & Smilax spinosa Mill. & -25.93 \\
\hline & $-26.62(3)$ & Malpighiaceae & Heteropteris chrysophylla (Lam.) Kunth & -29.11 \\
\hline & \multirow[t]{4}{*}{$-25.03(4)$} & Clusiaceae & Clusia lanceolata Camb. & -28.16 \\
\hline & & Ericaceae & Gaylussacia brasiliensis (Spreng.) Meisn. & -28.56 \\
\hline & & Malpighiaceae & Stigmaphyllon paralias Juss. & -28.63 \\
\hline & & Myrtaceae & Myrciaria sp. & -29.74 \\
\hline \multirow{5}{*}{ Herbaceous marsh } & \multirow{2}{*}{$-26.14(1)$} & Alismataceae & Sagittaria lancifolia $\mathrm{L}$. & -25.52 \\
\hline & & Thyphaceae & Typha domingensis Pers. & -29.49 \\
\hline & $-21.84(2)$ & Rubiaceae & sp1 & -26.72 \\
\hline & \multirow{2}{*}{$-27.84(3)$} & Cyperaceae & Fuirena umbellata Rottb. & -27.33 \\
\hline & & Cyperaceae & Eleocharis subaruculata (Nees) Boeckler & -26.43 \\
\hline \multirow{3}{*}{ Slack } & \multirow{3}{*}{-22.41} & Verbenaceae & Stachytarpheta sp. & -29.26 \\
\hline & & Rubiaceae & $\mathrm{sp} 2$ & -15.2 \\
\hline & & Erythroxylaceae & Erythroxylum ovalifolium Peyr. & -27.17 \\
\hline \multirow{3}{*}{ Shrubby vegetation } & \multirow{3}{*}{-28.47} & Apiaceae & Hydrocotyle bonariensis Lam. & -31.87 \\
\hline & & Asteraceae & Vernonia sp. & -30.37 \\
\hline & & Fabaceae & Dalbergia ecastaphyllum (L.) Taub. & -29.93 \\
\hline \multirow{4}{*}{ Dry forest } & \multirow[b]{2}{*}{$-24.3(1)$} & Maranthaceae & Calathea sp. & -31 \\
\hline & & Bromeliaceae & Bromelia antiacantha Bertoloni & -14.95 \\
\hline & \multirow[t]{2}{*}{$-26.61(2)$} & Arecaceae & Astrocaryum aculeatissimum (Schott) Burret & -31.18 \\
\hline & & Clusiaceae & Clusia sp. & -32.52 \\
\hline
\end{tabular}

(-13.1), Andropogon leucostachyus (-11.8), Andropogon sp. (-11.7), Andropogon sp 2 (-12.6); as well as some species of Cyperaceae: Cyperus sp (-12.4), Fimbristylis sp. (-12.7), Kyllinga sp (-11.8).. Krull et al. (2005), in a study conducted in Queensland, Australia, found similar values for some species of Poaceae such as Sporobolus actinocladus (-14.3), Sporobolus caroli (-13.0) and Panicum decompositum (-14.0). Similarly, the data presented by Boutton et al. (1998) for plants of subtropical savanna showed very close results for the species Panicum hallii var. filipes (Scribn.) Waller (- 14.4).
For sediment sample 3 , the value was -18.43 , indicating a mixture of $\mathrm{C} 3$ plants (the same as samples 1 and 2), but with the presence of $\mathrm{C} 4$ grasses, such as the Poaceae Stenotaphrum secundatum (-11.51) and some CAM plants (Cactaceae).

\section{B) "SCRUB" COMmunity over the Holocene BARRIER}

$\delta 13 \mathrm{C}$ analysis of the sediment sample presented the value of -26.35 , indicating a predominance of $\mathrm{C} 3$ plants, in this case woody, such as Araceae Anthurium sp. (-28.34), 
Malpighiaceae Heteropteris chrysophylla (-29.11), Ericaceae Gaylussacia brasiliensis (-28.56), Clusiaceae Clusia aff. fluminensis (-26.59) and Smilacaceae Smilax spinosa (-25.93). These values are compatible with those found by Vidotto et al. (2007) for the plants: Malpighiaceae Byrsonima sp 1 (-27.8), Clusiaceae Caraipa savannarum (-28.8), Myrtaceae Eugenia sp. (-33.1), Clusiaceae Vismia guianensis (-30.9), Arecaceae Mauritiella armata (-29.3) and Bromeliaceae Ananas ananassoides (-16.1). In this community C4 grasses, such as Poaceae Stenotaphrum secundatum $(-11.51)$ can also be found.

\section{C) HERBACEOUS SWAMP COMMUNITY BETWEEN THE TWO SANDY BARRIERS}

The $\delta 13 \mathrm{C}$ value obtained for the first sediment sample was -26.14 and -21.84 for the second sample. These values indicate a predominance of non-woody C3 plants like Alismataceae Sagittaria lancifolia (-25.52), Rubiaceae sp1 (-26.72) and Cyperaceae Eleocharis subariculata (-26.43). In southern Amazonas, other species of Rubiaceae and Cyperaceae families presented very close values, such as those of Alibertia edulis (-30.6) and Rhynchospora sp. (-28.5), respectively (VIDOTTO et al., 2007).

\section{D) SLACK COMMUNITY}

The $\delta 13 \mathrm{C}$ value obtained for the sediment sample was -22.41 , indicating the occurrence of a mixture of $\mathrm{C} 3$ plants such as Verbenaceae Stachytarpheta sp. (-29.26) and Erythroxylaceae Erythroxylum ovalifolium (-27.17), but with a predominance of $\mathrm{C} 4$ plants like Poaceae Stenotaphrum secundatum (-11.51) and Rubiaceae sp 2 (-15.2).

\section{E) “Scrub" Community over the Pleistocene BARRIER}

For sediment sample 1 the $\delta 13 \mathrm{C}$ value was -22.25 . For sample 2 it was -26.62 and for the third sample -25.03 . Similarly to the scrub over the Holocene barrier, these values indicate a predominance of $\mathrm{C} 3$ plants, in this case woody, such as Ericaceae sp 1 (-27.99), Clusiaceae Clusia lanceolata (-28.16), Malpighiaceae Heteropteris chrysophylla (-29.11), Malpighiaceae Stigmaphyllon paralias (-28.63), Arecaceae Allagoptera arenaria (-26.68) and Myrtaceae Myrciaria (-29.74) and the facultative CAM Bromeliaceae Neoregelia cruenta (-12.68). Vidotto et al. (2007) found similar values for other species of the Arecaceae family: Mauritiella armata (-29.3),
Oenocarpus bacaba (-31.4), Oenocarpus bataua (-31.3) and Socratea exorrhiza (-31.4). Approximate values were also found by the same authors for the plant Ananas ananassoides (-16.1) of the Bromeliaceae family.

\section{F) HERBACEOUS MARSH COMMUNITY TO THE REAR of the PLEISTOCENE BARRIER}

The $\delta 13 \mathrm{C}$ value of the sediment sample collected in this community was -27.84 , indicating a predominance of C3 plants, in this case non-woody, such as Cyperaceae Fuirena umbellata (-27.33) and Thyphaceae Typha domingensis (-29.49).

\section{G) Shrubby VEGETATION COMMUNity ON THE BANKS OF MARICÁ LAGOON}

In this sample the value of $\delta 13 \mathrm{C}$ obtained was -28.47 , indicating a predominance of $\mathrm{C} 3$ plants, in this case woody, such as Asteraceae Vernonia sp.(-30.37) and Fabaceae Dalbergia ecastaphyllum (-29.93) and non-woody plants like Apiaceae Hydrocotyle bonariensis (-31.87).

\section{H) DRY FOREST COMMUNITY}

$\delta 13 \mathrm{C}$ values obtained for sediment samples 1 and 2 were -24.3 and -26.61 , respectively, indicating the predominance of $\mathrm{C} 3$ plants, woody in this case, such as Arecaceae Astrocaryum aculeatissimum (-31.18), Clusiaceae Clusia sp. (-32.52), Maranthaceae Calathea sp. (-31) and some CAM plants such as Bromeliaceae Bromelia antiacantha Bertoloni (-14.95). Vidotto et al. (2007) obtained a similar $\delta 13 \mathrm{C}$ value for Marantaceae Monotagma sp. (-29.6).

\section{CONCLUSION}

Generally, the species that form the plant communities on the Maricá coastal plain, Rio de Janeiro, Brazil, produce no or only very low amounts of opal phytoliths. Only the species belonging to the Poaceae, Cyperaceae and Arecaceae families produce opal phytoliths in large amounts with diversity of morphotypes, besides the characteristic diagnostic opal phytoliths. Except for the Arecaceae family, where the major opal phytoliths produced are associated with fibers, the morphotypes observed in other producing species are associated with epidermal tissue. In species where trace amounts of opal phytoliths are produced, the other tissue involved in the silicification process is vascular tissue. 
The isotopic results of sediment samples demonstrated a good correspondence with the results from plants collected in each community, indicating that isotopes are good proxies for the vegetation reconstruction in the area. In the case of fossil samples, the phytolith studies may complement the isotopic ones, distinguishing, in the case of C3 plants, if they are woody or not.

The Maricá coastal plain has been undergoing a haphazard urbanization process, affecting ecosystems and modifying its landscape. We hope that studies on vegetation dynamics and the evolution of the region will contribute to its sustainable development. In the paleoenvironmental reconstruction studies, the starting point must be the knowledge of the current ecosystem. We believe, therefore, in the importance of this study for the construction of a basis for further paleoenvironmental studies in the Maricá restinga.

\section{ACKNOWLEDGEMENTS}

The authors would like to thank the Brazilian funding agency FAPERJ, the Agencia Nacional de Promoción Científica y Tecnológica, Ministerio de Ciencia y Técnica (PICT 2036-2010, PICT 1871-2010) and Universidad Nacional de Mar del Plata (EXA 643/13) for their financial support.

\section{REFERENCES}

ARAUJO, D. S. D.; HENRIQUES, R. P. B. Análise florística das restingas do Estado do Rio de Janeiro. In: Lacerda, L. D.; CERQUEIRA, R., TURCQ, B. (Eds.). Restingas: origens, estrutura, processos. Niterói: CEUFF, 19984. p. 159-193.

BORRELLI, N.; FERNÁNDEZ, H M.; ALTAMIRANO, S. M., OSTERRIETH, M. Calcium and silica biomineralization in leaves of eleven aquatic species of the Pampean Plain, Argentina. Aquat. Bot., v. 94, n. 1, p. 29-36, 2011.

BERRIER, A.; PROSSER, J. S. Automated analysis of light-element stable isotopes by isotope ratio mass spectrometry. In: BOUTTON, T. W.; YAMASAKI, S. I. (Ed.). Mass spectrometry of soils. New York: Marcel Dekker, 1996. p.1-17.

BOUTTON, T. W.; ARCHER, S. R.; MIDWOOD, A. J.; ZITZER, S. F.; BOL, R. $\delta 13 \mathrm{C}$ values of soil organic carbon and their use in documenting vegetation change in a subtropical savanna ecosystem. Geoderma, v. 82, n. 1/3, p. 5-41, 1998.

BUJÁN, E. Elemental composition of phytoliths in modern plants (Ericaceae). Quat. Int., v. 287, p. 114-120, 2013.

BUSO JUNIOR, A. A.; PESSENDA, L. C. R.; OLIVEIRA, P. E. D.; GIANNINI, P. C. F.; COHEN, M. C. L.; VOLKMER-RIBEIRO, C.; OLIVEIRA, S. M. B.; ROSSETTI, D. F.; LORENTE, F. L.; FILHO, M. A. B.; SCHIAVO, J. A.; BENDASSOLLI, J. A.; FRANÇA, M. C.; GUIMARÃES, J. T. F.; SIQUEIRA, G. S. Late Pleistocene and Holocene Vegetation, Climate Dynamics, and Amazonian Taxa in the Atlantic Forest, Linhares, SE Brazil. Radiocarbon, v. 55, n. 2/3, p. 1747$1762,2013$.
CARNELLI, A. L.; THEURRILAT, J. P.; MADELLA, M. Phytolith types and type-frequencies in subalpine-alpine plant species of the European Alps. Rev. Palaeobot. Palynol., v. 129, n. 1/2, p. 39-65, 2004.

CHANDLER-EZELL, K.; PEARSALL, D. M.; ZEIDLER, J. A. Root and tuber phytoliths and starch grains document manioc (Manihot esculenta), arrowroot (Maranta arundinacea), and llerén (Calathea sp.) at the Real Alto Site, Ecuador. Econ. Bot., v. 60, n. 2, p. 103-120, 2006.

COE, H. H. G.; ALEXANDRE, A.; CARVALHO, C. N.; SANTOS, G. M.; SILVA, A. S.; SOUSA, L. O. F.; LEPSCH, I. F. Changes in Holocene tree cover density in Cabo Frio (Rio de Janeiro, Brazil): Evidence from soil phytolith assemblages. Quat. Int., v. 2, p. 1-10, 2012.

CONSELHO NACIONAL DO MEIO AMBIENTE. Resolução CONAMA n 303 de 20 de março de 2002. Available at: <www.mma.gov.br/port/conama/res/res02/res30302.html>. Accessed on: 16 Mar. 2014.

CORTE, J. Biomas de Restinga. Dez. 2009. Available at: <http:// www.pt.slideshare.net/JadeCorte/bioma-restinga $>$. Accessed on: 5 Feb. 2014.

FERNÁNDEZ- HONAINE, M.; ZUCOL, A. F.; OSTERRIETH, M. Phytolith Assemblages and Systematic Associations in Grassland Species of the South-Eastern Pampean Plains, Argentina. Ann. Bot., v. 98, n. 6, p. 1155-1165, 2006.

FERNÁNDEZ- HONAINE, M.; ZUCOL, A. F.; OSTERRIETH, M. Phytolith analysis of Cyperaceae from the Pampean Region, Argentina. Austr. J. Bot., v. 57, p. 512-523, 2009.

KEALHOFER, L.; PIPERNO, D. R. Opal Phytoliths in Southeast Asian Flora. Smithsonian Contributions to Botany, v. 88, p. 1-39, 1998.

KILLOPS, S.; KILLOPS, V. Introduction to organic geochemistry. Malden: Blackwell, 2005. 393 p.

KRULL, E. S.; SKJEMSTAD, J. O.; BURROWS, W. H.; BRAY, S. G.; WYNND, J. G.; BOLE, R.; SPOUNCERA, L.; HARMSB, B. Recent vegetation changes in central Queensland, Australia: Evidence from d13C and $14 \mathrm{C}$ analyses of soil organic matter. Geoderma, v. 126, p. 241-259, 2005.

IRELAND, S. The Holocene sedimentary history of the coastal lagoons of Rio de Janeiro State, Brazil. In: Sea Level Changes. TOOLEY, M.; SHENNAM, I. (Eds.). Oxford: Brazil Blackwell Ltd, 1987. p. 25-66.

LABOURIAU, L. G. Phytolith work in Brazil: a minireview. Phytolitharien Newsletter, v. 2, n. 6-10, 1983.

LAMEGO, A. R. Restingas na Costa do Brasil. Divisão de Geologia e Mineralogia. Boletim DNPM, v. 96, p. 63, 1940.

LAMEGO, A. R. Ciclo Evolutivo das Lagunas Fluminenses. Divisão de Geologia e Mineralogia. Boletim DNPM, v, 118, p. 47,1945

LOUREIRO, D. S.; MATIAS, M. L.; FREIRE, D. G. Avaliação do conflito sócio-ambiental na APA da restinga de Maricá-RJ. XVI Encontro Nacional dos Geógrafos. Porto Alegre, 2010. $10 \mathrm{p}$.

MADELA, M.; ALEXANDRE, A; BAL, T. International code for phytolith nomenclature 1.0. Ann. Bot., v. 96, p. 253-260, 2005.

MERCADER, J.; BENETT, T.; ESSELMONT, C.; SIMPSON, S.; WALDE, D. Phytoliths in woody plants from the Miombo woodlands of Mozambique. Ann. Bot., v. 104, n. 1, p. 91-113, 2009 . 
MERCADER, J.; ASTUDILLO, F.; BARKWORTH, M.; BENETT, T.; ESSELMONT, C.; KINYANJUI, R.; GROSSMAN, D. L.; SIMPSON, S.; WALDE. D. Poaceae phytoliths from the Niassa Rift, Mozambique. J. Archaeol. Sci., v. 37, n. 8, p. 1953-1967, 2010.

MORRIS, L.; BAKER, F.; MORRIS, C.; RYEL, R. Phytolith types and type-frequencies in native and introduced species of the sagebrush steppe and pinyon-juniper woodlands of the Great Basin, USA. Rev. Palaeob. Palynol., v. 157, n. 3/4, p. 339-357, 2009.

MUEHE, D. C. E. H. Evidências de recuo dos cordões litorâneos em direção ao continente no litoral do Rio de Janeiro. In: LACERDA, L. D.; ARAUJO, D. S. D.; CERQUEIRA, R.; TURCQ, B. (Ed.). Restingas: origem, estruturas e processos. Anais do Simpósio sobre Restingas Brasileiras. Niterói: CEUFF, 1984. p.75-80.

MUEHE, D. C. E. H.; CORRÊA, C. H. T. The Coastline Between Rio de Janeiro and Cabo Frio. Coastlines of Brazil. New York: American Society of Civil Engineers, 1989. p. 110-123.

MULHOLAND, S. C.; RAPP, G. A morphological classification of grass silica-bodies. In: RAPP, G.; MULHOLAND, S. C. (Eds.). Phytolith systematics. New York: Plenum Press, 1992. p. 65-89.

OLIVEIRA, L.; NASCIMENTO, R.; KRAU, L.; MIRANDA, A. Observações biogeográficas e hidrobiológicas sobre a lagoa de Maricá. Mem Inst Oswaldo Cruz, v. 53, p. 171-227, 1955.

PARR, J. F.; SULLIVAN, L. A. Soil carbon sequestration in phytoliths. Soil. Biol. Bioch., v. 37, n. 1, p. 117-124, 2005.

PEREIRA, A. J.; GAMBÔA, L. A. P.; SILVA, M. A. M.; RODRIGUES, A. R.; COSTA, A. A utilização do Ground Penetrating Radar (GPR) em estudos de estratigrafia na praia de Iataipuaçú - Maricá (RJ). Rev. Bras. Geof., v. 21, n. 2, p. 163-171, 2003.

PERRIN, P. Evolução da Costa Fluminense entre as Pontas de Itacoatiara e Negra, preenchimentos e restingas. In: Restingas, origens, processos. LACERDA, L. D.; ARAUJO, D. S. D.; CERQUEIRA, R.; TURCQ, B. (Eds.). Niterói: CEUFF, 1984. p. 65-74.

PIPERNO, D. Phytolith Analysis: An Archaeological and Geological Perspective. New York: Academic Press, 1988.

PIPERNO, D. Phytoliths. A Comprehensive Guide for Archaeologists and Paleoecologists. Oxford: AltaMira Press, 2006.

SILVA, J. G.; OLIVEIRA, A. S. A vegetação de restinga no município de Maricá - RJ. Acta Bot. Bras., v. 3, supl. 2, p. 253$272,1989$.
SILVA, A. L. C.; SILVA, M. A. M.; SANTOS, C. L. Comportamento Morfológico e Sedimentar da Praia de Itaipuaçú (Maricá, RJ) nas últimas Três Décadas. Rev. Bras. Geoci., v. 38, n. 1, p. 89-99, 2008a.

SILVA, A. L. C.; SILVA, M. A. M.; GAMBÔA, L. A. P.; RODRIGUES, A. R. Sedimentary architecture and depositional evolution of the quaternary coastal plain of Maricá, Rio de Janeiro, Brazil. Braz. J. Geol., v. 44, n. 2, p. 191-206, 2014a.

SILVA, A. L. C.; SILVA, M. A. M.; GRALATO, J. C. A.; SILVESTRE, C. P. Caracterização geomorfológica e sedimentar da planície costeira de Maricá (Rio de Janeiro). Rev. Bras. Geomorf., v. 15, n. 2, p. 231-249, 2014 b.

SUGUIO, K.; TESSLER, M. G. Planícies de cordões litorâneos do Brasil: origem e nomeclatura. In: LACERDA, L. D. (Org.). Restingas: origens, estruturas e processos. Niterói: CEUFF, 1984. p. 195-216.

SUGUIO, K. Geologia sedimentar. São Paulo: Edgard Blucher Ltda, 2003. $400 \mathrm{p}$

THORN, C. C. Phytoliths from subantarctic Campbell Island: plant production and soil surface spectra. Rev. Palaeob. Palynol., v. 132, n. 1/2, p. 37-59, 2004.

TURCQ, B.; MARTIN, L.; FLEXOR, J. M.; SUGUIO, K.; PIERRE, C.; TASAYCO-ORTEGA, L. Origin and evolution of the Quaternary coastal plain between Guaratiba and Cabo Frio, State of Rio de Janeiro, Brazil. In: KNOPPERS, B.; BIDONE, E. D.; ABRAO, J. J. (Eds.). Environmental Geochemistry of Coastal Lagoon Systems. Série Geoquímica Ambiental 6, Rio de Janeiro, Brazil. Niterói: UFF/FINEP, 1999. p. 25-46.

VIDOTTO, E.; PESSENDA, L. C. R.; RIBEIRO, A. S.; FREITAS, H. A.; BENDASSOLLI, J. A. Dinâmica do ecótono floresta-campo no sul do estado do Amazonas no Holoceno, através de estudos isotópicos e fitossociológicos. Acta Amazônica, v. 37, n. 3, p. 385-400. 2007.

VILLWOCK, J. A. A costa brasileira: geologia e evolução. Anais III Simpósio de Ecossistemas da Costa Brasileira - Subsídios a um Gerenciamento Ambiental, Publ. ACIESP, São Paulo, v. 3, n. 87, p. 1-15, 1994.

WALLIS, L. An overview of leaf phytolith production patterns in selected northwest Australian flora. Rev. Palaeob. Palynol., v. 125, n. 3/4, p. 201-248, 2003.

ZAGATTO, E. C. A., CALHEIROS, D. F. S. Isótopos de Carbono em Estudos Ambientais. 15 p. 2000. Disponível em: $<$ http:// web.cena.usp.br/apostilas/Zagatto/FAN2-CarbonoAmbiente. doc $>$. Acesso em: 13 de Jun 2009. 